\title{
The other empire
}

Metropolis, India and progress in the colonial imagination

\section{JOHN MARRIOTT}




\section{\begin{tabular}{l} 
- STUDIES IN- \\
IMPERIALISM \\
\hline
\end{tabular}}

general editor John M. MacKenzie

When the 'Studies in Imperialism' series was founded by Professor John M. MacKenzie more than thirty years ago, emphasis was laid upon the conviction that 'imperialism as a cultural phenomenon had as significant an effect on the dominant as on the subordinate societies'. With well over a hundred titles now published, this remains the prime concern of the series. Cross-disciplinary work has indeed appeared covering the full spectrum of cultural phenomena, as well as examining aspects of gender and sex, frontiers and law, science and the environment, language and literature, migration and patriotic societies, and much else. Moreover, the series has always wished to present comparative work on European and American imperialism, and particularly welcomes the submission of books in these areas. The fascination with imperialism, in all its aspects, shows no sign of abating, and this series will continue to lead the way in encouraging the widest possible range of studies in the field. Studies in Imperialism is fully organic in its development, always seeking to be at the cutting edge, responding to the latest interests of scholars and the needs of this everexpanding area of scholarship.

The other empire 


\title{
AVAILABLE IN THE SERIES
}

\author{
CULTURAL IDENTITIES AND THE AESTHETICS OF BRITISHNESS ed. Dana Arnold \\ BRITAIN IN CHINA \\ Community, culture and colonialism, 1900-1949 Robert Bickers \\ NEW FRONTIERS \\ Imperialism's new communities in East Asia 1842-1952 \\ eds Robert Bickers and Christian Henriot \\ WESTERN MEDICINE AS CONTESTED KNOWLEDGE \\ eds Andrew Cunningham and Bridie Andrews \\ THE ARCTIC IN THE BRITISH IMAGINATION 1818-1914 \\ Robert G. David \\ IMPERIAL CITIES Landscape, display and identity \\ eds Felix Driver and David Gilbert \\ SCIENCE AND SOCIETY IN SOUTHERN AFRICA ed. Saul Dubow \\ EQUAL SUBIECTS, UNEQUAL RIGHTS \\ Indigenous peoples in British settler colonies, 1830s-1910 \\ Julie Evans, Patricia Grimshaw, David Phillips and Shurlee Swain \\ EMIGRATION FROM SCOTLAND BETWEEN THE WARS \\ Opportunity or exile? Marjory Harper \\ EMPIRE AND SEXUALITY \\ The British experience Ronald Hyam \\ REPORTING THE RAJ \\ The British press in India, c. 1880-1922 Chandrika Kaul \\ LAW, HISTORY, COLONIALISM \\ The reach of empire eds Diane Kirkby and Catherine Coleborne \\ THE SOUTH AFRICAN WAR REAPPRAISED ed. Donal Lowry \\ THE EMPIRE OF NATURE \\ Hunting, conservation and British imperialism John M. MacKenzie \\ IMPERIALISM AND POPULAR CULTURE ed. John M. MacKenzie \\ PROPAGANDA AND EMPIRE \\ The manipulation of British public opinion, 1880-1960 John M. MacKenzie \\ GENDER AND IMPERIALISM ed. Clare Midgley \\ GUARDIANS OF EMPIRE The armed forces of the colonial powers, c. 1700-1964 \\ eds David Omissi and David Killingray \\ FEMALE IMPERIALISM AND NATIONAL IDENTITY \\ Imperial Order Daughters of the Empire Katie Pickles \\ MARRIED TO THE EMPIRE \\ Gender, politics and imperialism in India, 1883-1947 Mary A. Procida \\ IMPERIAL PERSUADERS \\ Images of Africa and Asia in British advertising Anandi Ramamurthy \\ IMPERIALISM AND MUSIC Britain 1876-1953 Jeffrey Richards \\ COLONIAL FRONTIERS \\ Indigenous-European encounters in settler societies ed. Lynette Russell \\ WEST INDIAN INTELLECTUALS IN BRITAIN ed. Bill Schwarz \\ JUTE AND EMPIRE \\ The Calcutta jute wallahs and the landscapes of empire Gordon T. Stewart \\ THE IMPERIAL GAME Cricket, culture and society \\ eds Brian Stoddart and Keith A. P. Sandiford \\ BRITISH CULTURE AND THE END OF EMPIRE ed. Stuart Ward
}




\title{
The other empire \\ Metropolis, India and progress in the colonial imagination
}

\author{
John Marriott
}

MANCHESTER

UNIVERSITY PRESS

Manchester 
Copyright (C) John Marriott 2003

The right of John Marriott to be identified as the author of this work has been asserted by him in accordance with the Copyright, Designs and Patents Act 1988.

Published by MANCHESTER UNIVERSITY PRESS

ALTRINCHAM STREET, MANCHESTER M1 7JA

www.manchesteruniversitypress.co.uk

British Library Cataloguing-in-Publication Data

A catalogue record for this book is available from the British Library

Library of Congress Cataloging-in-Publication Data applied for

ISBN 0719060184 hardback

First published 2003

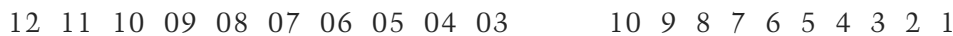

